\title{
The impact of climate variability on tobacco productivity over Temanggung Regency, Indonesia
}

\author{
Andi Syahid Muttaqin ${ }^{1, *}$, Utia Suarma $^{2}$,Emilya Nurjani $^{2}$, Faricha Kurniadhini $^{3}$, Ratna Prabaningrum ${ }^{2}$, and Retno \\ Wulandari ${ }^{2}$
}

${ }^{1}$ Faculty of Agriculture, Universitas Gadjah Mada, Yogyakarta, Indonesia

${ }^{2}$ Faculty of Geography, Universitas Gadjah Mada, Yogyakarta, Indonesia

${ }^{3}$ Master Student, Faculty of Engineering, Universitas Gadjah Mada, Yogyakarta, Indonesia

\begin{abstract}
Indonesia is among the most affected regions by climate variability and change. Located between the Pacific and the Indian Ocean, Indonesia is mostly influenced by some climate variabilities, such as the monsoon, El-Nino Southern Oscillation (ENSO), and Indian Ocean Dipole (IOD). These climate variabilities affect significantly on the Indonesian rainfall that further increase the chances of crop failure, specifically on the tobacco yield over Temanggung Regency which is known as the producer of good quality tobacco in Indonesia. Tobacco needs a sufficient dry condition prior to the harvest stage due to maintains its productivity and leaf quality. This ideal condition could be achieved when the dry season, typically in the mid of the year for Temanggung, is not affected by any wet climate variability. Moreover, based on this study, it was found that there was the most remarkable decline in tobacco productivity in 2016 since the required dry condition was interrupted by the prolonged significant rainfall which depicted by strong mid-year negative-IOD indices. The analysis utilized the dataset of tobacco productivity, daily rainfall intensity, and the indices of monsoon, ENSO, and IOD for the period of seven years, from 20102016. This study concludes that the climate variabilities give a huge contribution to the profitable tobacco cultivation. Furthermore, efforts to adapt and to mitigate the impacts of the climate variability in Indonesia, specifically for the agriculture sector, is needed by way of increasing the various stakeholder's knowledge that involved in policy planning and decision-making as well as involving the farmers in the training on climate adaptation and mitigation.
\end{abstract}

\section{Introduction}

Climate change is defined as "a change of climate which is attributed directly or indirectly to human activity that alters the composition of the global atmosphere" [1]. Climate change may cause extreme events that affect ecological, social or economic systems via changes in its magnitude and frequency. Studies indicated that there are an increasing number of impacts on deaths, injuries, and economic losses due to extreme weather events [2]. According to IPCC, developing countries like in Asia are much more affected by extreme events of 20-30 times larger than in developed countries. It is caused by the low socioeconomic conditions.

Indonesia is among the most affected regions by climate change [3]. Indonesia is located over the equatorial zone which makes it has tropical climate. The seasons in Indonesia are hot and rainy season which caused by the monsoon system. According to its geographical location, Indonesia influenced by climate variability such as monsoon, ENSO, and IOD [4]. This climate variability affects Indonesian rainfall that influences on the chances of crop failure [5]. Hidayat et al. [6] stated that rainfall variability has strong influence that leads to devastating drought with losses in crop production.

Climate variability and change in Indonesia also affects the sector of industry, health, politics, and socialeconomic. In agricultural sector, climate change affects not only on its resources, but also on its infrastructure, production system, and security [7]. As a country that has a basic sector of agricultural, climate change has affected agricultural productivity. One of districts in Indonesia which experienced loss in agricultural productivity is Temanggung Regency, Central Java.

Temanggung Regency is located in the middle of Central Java Province, Java Island, Indonesia with North to South stretch $34,375 \mathrm{~km}$ and East to West $43,437 \mathrm{~km}$ (Figure 1). Temanggung Regency is astronomically located between $110^{\circ} 23^{\prime}-110^{\circ} 46^{\prime} 30$ "East longitude and $7^{\circ} 14^{\prime}-7^{\circ} 32^{\prime} 35^{\prime \prime}$ South latitude with an area of $870.65 \mathrm{~km} 2$ ( 87,065 ha). Temanggung is known as the producer of good quality tobacco in Indonesia. Tobacco from Temanggung Regency is used by many big cigarette companies as their raw materials. It is obvious that climate change has a direct impact on tobacco

\footnotetext{
* Corresponding author: andi.syahid@mail.ugm.ac.id
} 
productivity. Tobacco production contributes $21,5 \%$ of Gross Domestic Regional Product of Temanggung Regency in 2016 which laid in the second rank [8]. In addition, tobacco plantation also provides jobs for 55.171 household in Temanggung Regency.

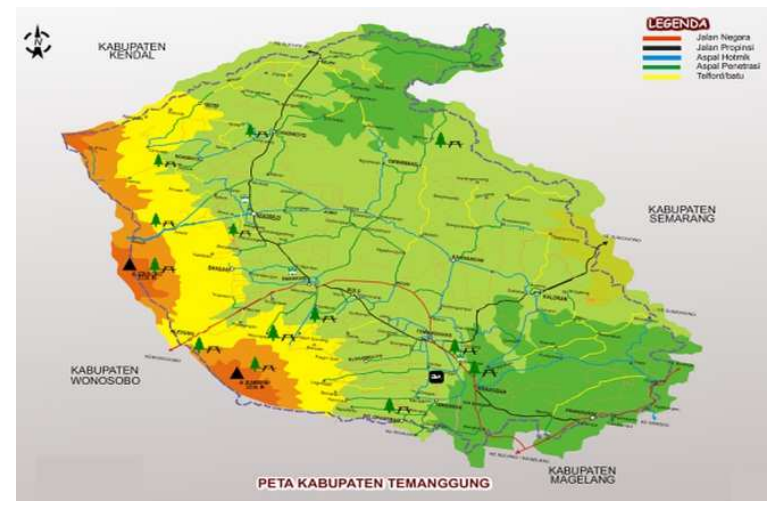

Fig. 1. Map of Temanggung Regency.

According to that reason, enhancing tobacco farmer's resilience capacity is important. Moreover, lack accessibility to climate information unable tobacco farmers to predict the precise time to plant and harvest the tobacco. Thus, understanding the impact of climate change on tobacco production in Temanggung Regency helps authorized government to make a better adaptation planning to gain tobacco productivity.

\section{Methods}

The methods and data used to understand the impact of climate change on tobacco production in Temanggung Regency are presented in the section below. The data are consisted of climate and tobacco production data. Climate data are collected from several agencies such as the Indonesian Agency for Meteorogical, Climatological, and Geophysics (BMKG), the Bureau of Meteorology (BoM) Australia, and the Asia-Pacific Data-Research Center (APDRC). Meanwhile, tobacco production data are collected from the Agriculture and Food Security Agency of Temanggung Regency.

The data are consisted of daily rainfall intensity, Monsoon Index, ENSO Index, IOD Index, and MJO Index. We use the indices as published by the agencies than proceed from the raw data with the intention to simplify the access and utilization of these indices by farmers. Combined with tobacco production data, the data are used to identify rainfall pattern and other climate variability pattern that are affected the condition of climate in Indonesia and tobacco production in Temanggung Regency. The data were combined bycomparing and complementing them to seek for the most precise data.

The method used in this research is descriptive quantitative. The climate change is identified by analyzing the patterns of climate variability. Furthermore, the patterns of climate variability are compared to tobacco production. Expert judgment is applied on this stage to know the impact of climate change on tobacco production. To ensure the validity of expert judgment, Focus Group Discussions (FGD) are conducted with tobacco farmers and facilitated by Agriculture and Food Security Agency of Temanggung Regency.

\section{Results and discussion}

The pattern of seasons in Indonesia is influenced by tropical climate variability. The influential climate phenomena in Indonesia are Monsoon, ENSO, IOD, and MJO. The phenomenon affects climate patterns in Indonesia and also affects the productivity of production crops, especially tobacco. Tobacco crops are very sensitive to climate change that will affect the planting, cultivation, and harvesting of the crops.

\subsection{Monsoon}

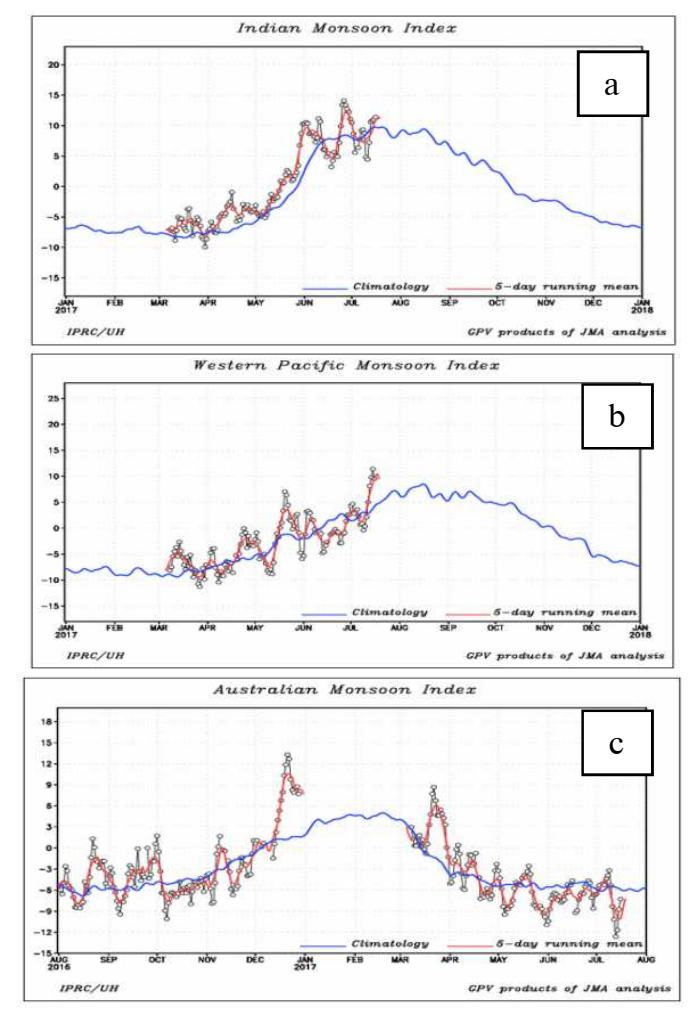

Fig. 2. Index of Indian Monsoon (a), Western North Pacific Monsoon (b), and Australian Monsoon (c) (Source: the AsiaPacific Data Research Center).

There are several monsoon indices that we can use to monitor monsoon conditions in Indonesia, namely the Asian monsoon and the Australian monsoon. The Asian monsoon is influenced by Indian Monsoon (IM) and Western North Pacific Monsoon (WNPM), while the Australian monsoon is influenced by Australia Monsoon (AUSM) [9]. Both monsoons affect the rainfall in Indonesia. The condition of the Indian monsoon of 2017 as seen from Figure 2 between June and July fluctuates with the deviation value of the considerable average conditions. In general, early June was strong, mid-June weakened, the end of June strong, early July weakened and increase again in July. 
The monsoon condition of 2017 based on the WNP monsoon between June and July is generally fluctuating. The graph shows the strengthening of the monsoon in early June, weakening and rising again in mid-June, but still below the average of the observed climatology. It then weakens and returns to strengthen in late June to early July. In early July again weakened and experienced a significant reinforcement in mid-July.

Similarly, the Australian monsoon condition in 2017, fluctuated. The Australian monsoon fluctuated during the month of June and is below the average of observed climatology while on early July it weakened and strengthen in mid-July.

\subsection{El Nino Southern Oscillation (ENSO)}

There are several indices used to monitor the tropical Pacific, all based on the average anomalous SST (Sea Surface Temperature) in a particular region. ENSO's phenomenon has an effect to the condition of Indonesia sea which is becoming cooler in El Nino year and warmer in La Nina year [10]. The Nino 3.4 index (Figure 3) and the ONI (Oceanic Nino Index) are the most commonly used indexes to define El Nino and La Nina events. Usually the anomaly is calculated relative to the base period of 30 years. Nino 3.4 is located at 5 N-5 S, $170 \mathrm{~W}-120 \mathrm{~W}$. By region, Nino 3.4 can be considered to represent the average equatorial SST across the Pacific from around the South American coastal boundary.

Graphic data from observations made by Bureau of Meteorology Australia (Figure 3) shows that a strong El Nino event characterized by an SST anomaly occurs in 2015 and the highest peak in December 2015. The implications of the El Nino event of 2015 still impacted early in 2016 and declining with the lowest peak in October 2016. Condition 2017 increased SST anomaly but not as high as in 2015 .

The graph shows that the year 2013 has a normal index close to La Nina, La Nina's worst phenomenon in 2016 approaching 2017. Nino 3.4 CFSv2 products (Figure 4) have 3 predictions of prediction of 0 months, 3 months, and 6 months. Observations from BMKG on some predictions made from Nino $3.4 \mathrm{CFSv} 2$ products show that the prediction of 0 months has a better accuracy because it tends to always follow the value of the average observation. According to Barnston and Tippett, CFSv2 has visibly better probabilistic reliability as compared with CFSv1 [11]. This can be seen in Figure 3, where the red line tends to keep following the black line.

\subsection{Indian Ocean Dipole (IOD)}

The world's IOD index is released by institutions such as Bureau of Meteorology Australia and Jamstec. The IOD chart shown in Figure 5 is a combination of 27 ensembles or modeling that shows the overall IOD index from January 2013 to July 2017. The IOD + index shows dry phenomena in Indonesia, while the IOD index indicates a wet phenomenon in Indonesia [12].
Based on the graph it can be seen that the phenomenon IOD - occurs in the month in the dry season is a phenomenon commonly called wet drought. The wet dryness phenomenon based on these graphs occurred in July-August 2013, July-August 2014, and the most severe occurred in July 2016.

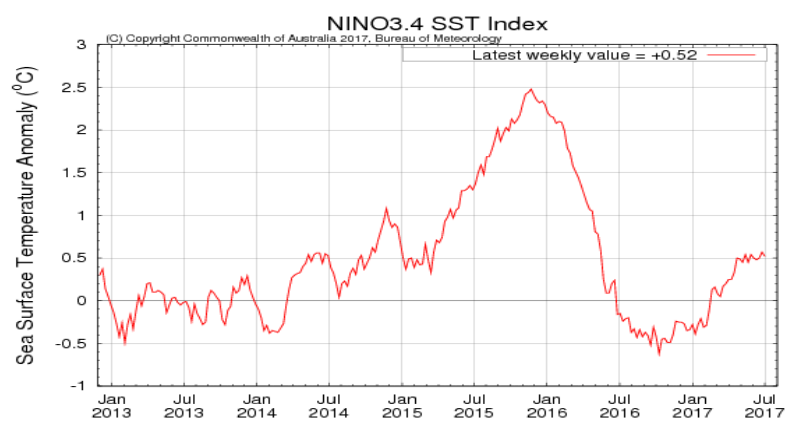

Fig. 3. Graph of Index of Sea Surface Temperature (SST) on Nino 3.4 (Source: Bureau of Meteorology Australia).

CFSv2 monthly SST indices (K)

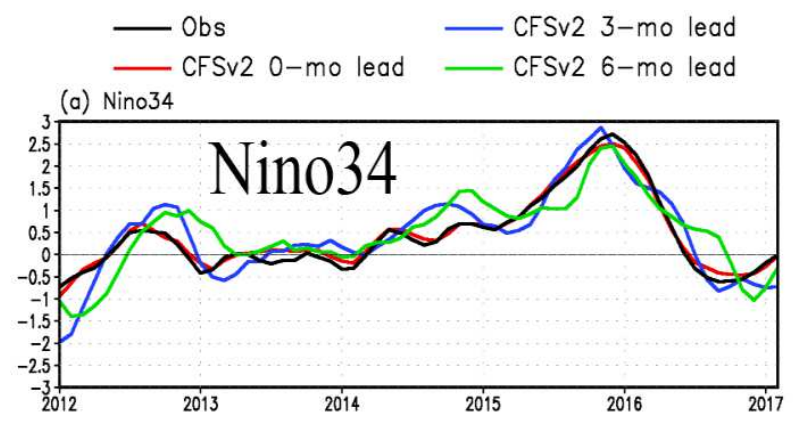

Fig. 4. Prediction graph of ENSO Nino 3.4 CFSv2 Products on 0 Months, 3 Months, and 6 Months on average observation data (Source: Climate Prediction Center, National Oceanic and Atmospheric Administration, USA).

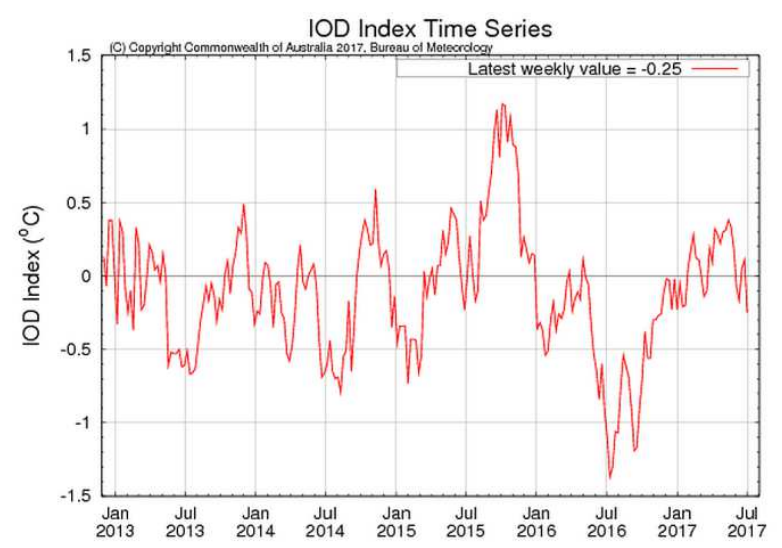

Fig. 5. IOD Index year 2013-2017 (Source: Bureau of Meteorology, Australia). 


\subsection{Climate variability monitoring}

Monitoring of climate phenomena could help seasons forecast. Information of climate phenomena can be obtained from the climatological bureau held by each country. These monitoring would give the information whether there is a shift in the pattern of season so it can anticipate the pattern of planting from production plants. These monitoring data is intended to predict the 2017 condition as it was used for the dissemination of climate variability information and prediction to tobacco farmers in Temanggung Regency.

Table 1. Summary of climate variability in Indonesia.

\begin{tabular}{|c|c|c|c|c|c|}
\hline \multirow{2}{*}{$\begin{array}{c}\text { Climate } \\
\text { Variability }\end{array}$} & \multicolumn{6}{|c|}{ Current condition } \\
\cline { 2 - 7 } & Jun-17 & Jul-17 & Agt-17 & Sep-17 & Oct-17 \\
\hline Monsoon & Strong & Weak & Weak & Weak & Weak \\
\hline \multirow{2}{*}{ ENSO } & $\begin{array}{c}\text { Weak } \\
\text { El Nino }\end{array}$ & $\begin{array}{c}\text { Weak } \\
\text { El } \\
\text { Nino }\end{array}$ & Normal & Normal & Normal \\
\hline IOD & Neutral & Neutral & Positive & $\begin{array}{c}\text { Positve } \\
\text { (peak) }\end{array}$ & Positive \\
\hline Season & Dry & Dry & Dry & Dry & Transition \\
\hline \multicolumn{7}{|c|}{ Forecast/Prediction } \\
\hline $\begin{array}{c}\text { Climate } \\
\text { Variability }\end{array}$ & Nov-17 & Dec-17 & Jan-18 & Feb-18 & Mar-18 \\
\cline { 2 - 7 } Monsoon & - & - & - & - & - \\
\hline \multirow{2}{*}{ ENSO } & $\begin{array}{c}\text { Weak La } \\
\text { Nina }\end{array}$ & $\begin{array}{c}\text { Weak } \\
\text { La } \\
\text { Nina }\end{array}$ & $\begin{array}{c}\text { Weak } \\
\text { La Nina }\end{array}$ & Normal & Normal \\
\hline IOD & Positive & Neutral & Neutral & Neutral & Neutral \\
\hline Season & Transition & Rainy & Rainy & Rainy & Rainy \\
\hline
\end{tabular}
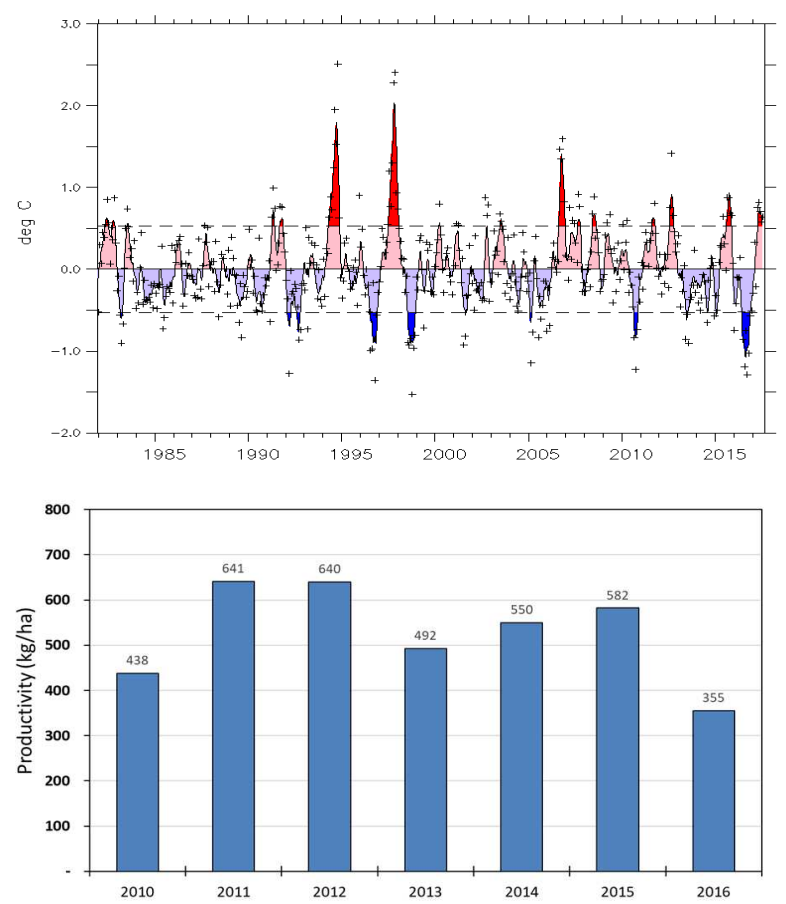

Fig. 6. Comparison between IOD Index (degree Celcius) and tobacco production $(\mathrm{kg} / \mathrm{ha}$ ) from 2010-2016 (Source: Agency of Agriculture and Food Security of Temanggung Regency).

Table 1 shows the IOD index is a climate variability that provides a strong estimate of the end of the dry season. Positive IOD index means that Indonesia experiencing dry conditions occurred from August to November. However, based on average rainfall year period 1981-2010 end of dry season occurred in October. A positive IOD score in November indicated a possible shift in the end of the dry season.

Production data and area of tobacco area in Temanggung district in the period 2010-2016 is analyzed to find the value of productivity and shown in Figure 6. It explains the correlation between IOD index and tobacco productivity. As shown on the figure, severe IOD - occurred in 2010, 2013 and 2016 decreased tobacco production; all of the IOD indices were below 1.0 and the tobacco productions were below $500 \mathrm{~kg} / \mathrm{ha}$. Based on this condition, it is obvious that climate condition in Temanggung Regency is sensitive to IOD.

\section{Conclusion}

1. Decrease in tobacco productivity in 2013 and 2016 occur simultaneously with negative IOD phenomenon in Temanggung Regency. Negative IOD is the impact of climate variability that has the most influence on tobacco productivity in Temanggung Regency.

2. Efforts to mitigate and adapt to the impacts of climate variability in Temanggung are to increase the human resources of various stakeholders involved in policy planning and decision-making including by conducting climate schools, training on climate data references, climate data analysis, and how to use climate data.

This research is funded by the Government of Temanggung Regency through Agriculture and Food Security Agency. Authors would also like to thank the entire parties involved in the research in all stages.

\section{References}

1. UNFCCC. United Nations Framework Convention on Climate Change. Technical Report. UNFCCC (1992)

2. IPCC. Climate Change 2001: Impacts, Adaptation, and Vulnerability (2001)

3. Irwansyah. What do scientists say on climate change? A study of Indonesian newspapers. Pacific Science Review B: Humanities and Social Sciences 2, 58-65 (2016)

4. S.Y. Cahyarini \& M. Henrizan, Coral basedENSO/IOD related climate variability in Indonesia: a review. IOP Conference Series: Earth and Environmental Science. (2018)

5. I.N. Hidayati \& Suryanto. Pengaruh Perubahan Iklim Terhadap Produksi Pertanian dan Strategi Adaptasi Pada Lahan Rawan Kekeringan. Jurnal Ekonomi dan Studi Pembangunan Vol 16 No 1, 42$52(2015)$ 
6. R. Hidayat, K. Ando, Y. Masumoto, and J. Luo. J. Interannual Variability of Rainfall over Indonesia: Impacts of ENSO and IOD and Their Predictability. IOP Conference Series: Earth and Environmental Science doi:10.1088/1755-1315/31/1/012043 (2016)

7. Balitbangtan. Pedoman Umum Adaptasi Perubahan Iklim Sektor Pertanian. Jakarta: Kementerian Pertanian (2011)

8. Badan Pusat Statistik (BPS). Produk Domestik Regional Bruto Menurut Lapangan Usaha Kabupaten Temanggung 2012-2016. Badan Pusat Statistik (2016)

9. C. S. Ramage, Monsoon Meteorology. Academic Press (1971)

10. E. Aldrian, Meteorologi Laut Indonesia. Jakarta: Badan Meteorologi dan Geofisika. (2008)

11. A. G. Barnston \& M. K. Tippett, Predictions of Nino 3.4 SST in CFSv1 and CFSv2: a diagnostic comparison. Climate Dynamics Vol 41, 1615-1633 (2013)

12. M. N. Nur'utami \& R. Hidayat, Influences of IOD and ENSO to Indonesian Rainfall Variability: Role of Atmosphere-ocean Interaction in the Indo-pacific Sector. Procedia Environmental Sciences Vol 33, 196-203, https://doi.org/10.1016/j.proenv.2016.03.070 (2016)

13. Luigi T. De Luca, Propulsion physics (EDP Sciences, Les Ulis, 2009)

14. F. De Lillo, F. Cecconi, G. Lacorata, A. Vulpiani, EPL, 84 (2008) 